\title{
VALUABLE TRAITS OF POTATO (Solanum L.) VARIETIES AS INFLUENCED BY CLIMATE CHANGE IN EUROPEAN RUSSIA
}

\author{
L.Yu. NOVIKOVA, S.D. KIRU, E.V. ROGOZINA
}

Federal Research Center the N.I. Vavilov All-Russian Institute of Plant Genetic Resources, Federal Agency of Scientific Organizations, 42-44, ul. Bol'shaya Morskaya, St. Petersburg, 190000 Russia, e-mail 1.novikova@vir.nw.ru The authors declare no conflict of interests

ORCID: Kiru S.D. orcid.org/0000-0002-8648-3837

Received November 9, 2016

\section{Abstract}

Adaptation of regional assortment of crops to climatic changes necessitates numerical assessment of the observed trends in crop main characteristics and identification of the factors causing this dynamics. In previous research we revealed that valuable traits of cultivated varieties have significantly changed over the last decades. Objective of this research was to summarize our findings on the trends in variability of potato (Solanum tuberosum L.) valuable traits in the European Russia territory with special regard to climatic factors as causative ones. It was found out that most valuable traits of potatoes depend on temperature under lack or excess of heat. By correlation-regression analysis, the main agroclimatic factors defining development of potato plants in the European Russia are revealed. Increase in the sum of temperatures above $15{ }^{\circ} \mathrm{C}$ and earlier date for temperature to exceed $15{ }^{\circ} \mathrm{C}$ were those accelerating the most meteodependent phases, the germination and flowering. The long-time observations on phenology, weigh of marketable tuber per plant and starch content in standard varieties were evaluated in the conditions of regional experimental stations of N.I. Vavilov All-Russian Institute of Plant Genetic Resources (VIR). These were Polar Experimental Station (Murmansk region, variety Hibinskii rannii, 1968-2013), VIR Pushkin laboratories (St. Petersburg, varieties Nevskii, 1984-2004; Elizaveta, Petersburgskii 19992010), Maikop Experimental Station (the Republic of Adygea, variety Nevskii, 1990-2012). Correlation and regression analysis was used to determine significant climatic factors. It was shown that the most considerable variability of valuable traits occurred under lack (Polar Experimental Station) and excess (Maikop Experimental Station) of heat. In Murmansk region (Polar Experimental Station), planting to flowering period reduced at a decennial rate of 2.4 days, and the temperature sum for this period also decreased decennially by $15.9{ }^{\circ} \mathrm{C}$; in Adygea (Maikop Experimental Station) the decennial rates were 6.6 days and $73.8{ }^{\circ} \mathrm{C}$, respectively. The time from flowering to harvesting increased at Polar Experimental Station and reduced at Maikop Experimental Station. In Maikop region, the temperature sums during planting to harvesting decreased by $253.4{ }^{\circ} \mathrm{C}$ per decade. Under contrast climatic conditions, the temperature sums for interphase periods were less stable indexes than their durations. The tuber weight per plant and starchiness grew at Polar Experimental Station, whereas in the Maikop region the potato productivity increased while starchiness decreased. The obtained models allows to forecast further growth of potato productivity in European Russia caused by earlier flowering and extended period from flowering to harvesting. Earlier planting and involvement of more late-ripening varieties can be offered as a measure to update agro technologies for potato cultivation under climate changes in European Russia.

Keywords: potato, Solanum tuberosum, climate changes, phenology, productivity, starch content, stability, sums of temperatures above $15^{\circ} \mathrm{C}$

The period with temperatures comfortable for cultivated plants in Europe has been getting longer since mid-20th century, which has become a significant factor affecting modern agricultural industry [1, 2]. In France potato planting has been performed in average 5 days earlier per 10 years since 1980, in Germany planting and harvesting of cultivated plants accelerate by 2 days per 10 years [3-5]. However, in general, agricultural technologies have not yet adapted to climatic changes $[3,4]$. In the European Russia territory the changes observed affect the regional bioclimatic potential, heat supply increases, and the amount of precipitation grows in the north $[6,7]$. 
Heat and water supply conditions significantly affect potato plants both during active growth [8-10] and tuber formation period [8, 11, 12]. Requirements of this culture to climate are as follows: minimum temperature of vegetation start and end is $8-10{ }^{\circ} \mathrm{C}$, cold resistance is up to $-2 \ldots-3{ }^{\circ} \mathrm{C}[6,13]$, in northern varieties plant growth occurs at $2-3{ }^{\circ} \mathrm{C}$ [14]. Potato active vegetation zone is $10-20{ }^{\circ} \mathrm{C}$, growth optimum is $15^{\circ} \mathrm{C}$ [15-17], and tuber formation optimum is $16-18{ }^{\circ} \mathrm{C}[8,18]$. Vegetation continues above 60 days, the sum of average daily temperatures during vegetation must be no less than $1000-1400{ }^{\circ} \mathrm{C}[7$, $8,19]$. Optimum soil moisture is within $75-80 \%$ of full field water capacity in light soils and $40-55 \%$ in heavy soils [8].

It should be noted that agrometeorological models of potato yield in Russia are region-specific. In the west and north-west, where moisture conditions are favorable and average temperatures do not exceed the optimum value during tuber formation, the yield positively correlates with the temperature [20, 21]. In southern regions the yield positively correlates with moisture indices, while correlation with average air temperature is low negative [21, 22]. In central regions the yield is determined by deviation of temperatures and precipitations from optimum for each interphase period [21]. Starch content in potato tubers increases with an increase in temperature and decreases as the day becomes longer and the amount of precipitation increases (optimum amount per tuber formation period is $90-130 \mathrm{~mm}$ ) [22].

In previous studies we have demonstrated that changes in phenology of previously recognized varieties, their yield and starch content in tubers have been observed in recent decades. These effects were caused by increase in sums of temperatures and precipitation for the period with temperatures above $15^{\circ} \mathrm{C}$ and more early temperature increase above this value [23-26].

The long-term data obtained have been summarized for the first time in this paper, revealing the most significant correlation between variability of agriculturally valuable potato traits and the temperature in extreme conditions with regard to this index, i.e. lack or excess of heat. Increase in the sum of temperatures above $15{ }^{\circ} \mathrm{C}$ and more early temperature increase above $15{ }^{\circ} \mathrm{C}$, which accelerated the most weather-dependent phases (emergence and flowering), were considered the most important agroclimatic factors of potato development in the European Russia territory. The models developed suggest further increase in potato yields in the European Russia territory due to earlier flowering and longer tuber formation period.

The research was aimed at statistical analysis of observed trends in manifestation of the main agriculturally valuable traits of potato varieties in the European Russia territory with regard to regional climatic changes.

Techniques. Long-term observations of potato plant phenological phase, tuber weight per plant and starch content in tubers of varieties used as reference standards during examination of samples from potato collection of N.I. Vavilov All-Russian Institute of Plant Genetic Resources (VIR) were performed at VIR experimental stations (ES) with contrast climatic conditions, i.e. at VIR Polar ES (Murmansk region, early variety Hibinskii rannii, 1968-2013) and VIR Maikop ES (the Republic of Adygea, middle-early variety Nevskii, 1990-2012), as well as in central part of the country, at VIR Pushkin laboratories (St. Petersburg, variety Nevskii, 1984-2004; middle-early variety Elizaveta and mid-ripening variety Petersburgskii, 1999-2010). Weather conditions during the observation periods were registered based on daily data of the nearest meteorological stations.

Decennial rate of change of analyzed parameters was determined $(\Delta / 10$ years). Standard deviations $( \pm S)$ and variation coefficients $(C v, \%)$ of compared parameters were calculated. Correlation regression analysis was used for identifi- 
cation of significant climatic factors. Statistical data processing was performed using Statistica 6.0 software («StatSoft Inc.», USA). Regression models were developed using successive inclusion of variables, determination coefficients $\mathrm{R}^{2}$ were determined. Monthly temperatures, monthly precipitation totals, dates of stable temperature increase above 10 and $15{ }^{\circ} \mathrm{C}$, duration of periods with temperatures above these limits, sums of active (daily average, above the specified limit) and effective (daily average minus the specified temperature limit) air temperatures, total precipitation, as well as average active and effective temperatures during these periods were examined as possible independent variables. In equations the dates are presented as the number of days from the reference point (April 1). Significance level $5 \%(\mathrm{p}=0.05)$ is accepted in the study.

Results. More early change of temperatures has been observed since 1980 in all studied points: for values above $10{ }^{\circ} \mathrm{C}-$ with average rate of $0.5 ; 3.8$ and 1.5 days/10 years (VIR Polar ES, VIR Pushkin laboratories and VIR Maikop $\mathrm{ES}$, respectively); for values above $15{ }^{\circ} \mathrm{C}-$ for stations by $0.4 ; 0.6$ and 2.9 days/10 years, respectively. The changes of the sum of temperatures for stations amounted to $62.7 ; 205.1$ and $52.2^{\circ} \mathrm{C} / 10$ years, respectively, for values above $10{ }^{\circ} \mathrm{C} ; 36.4 ; 218.4$ and $101.1{ }^{\circ} \mathrm{C} / 10$ years, respectively, for values above $15{ }^{\circ} \mathrm{C}$. A small increase in total precipitation during the periods with temperatures above $10,15^{\circ} \mathrm{C}$ was observed in all observation points; however, it was statistically insignificant.

1. Trends of agroclimatic factor changes during interphase vegetation periods of reference potato varieties (Solanum tuberosum $\mathbf{L}$.) in observation points with optimum and extreme meteorological conditions

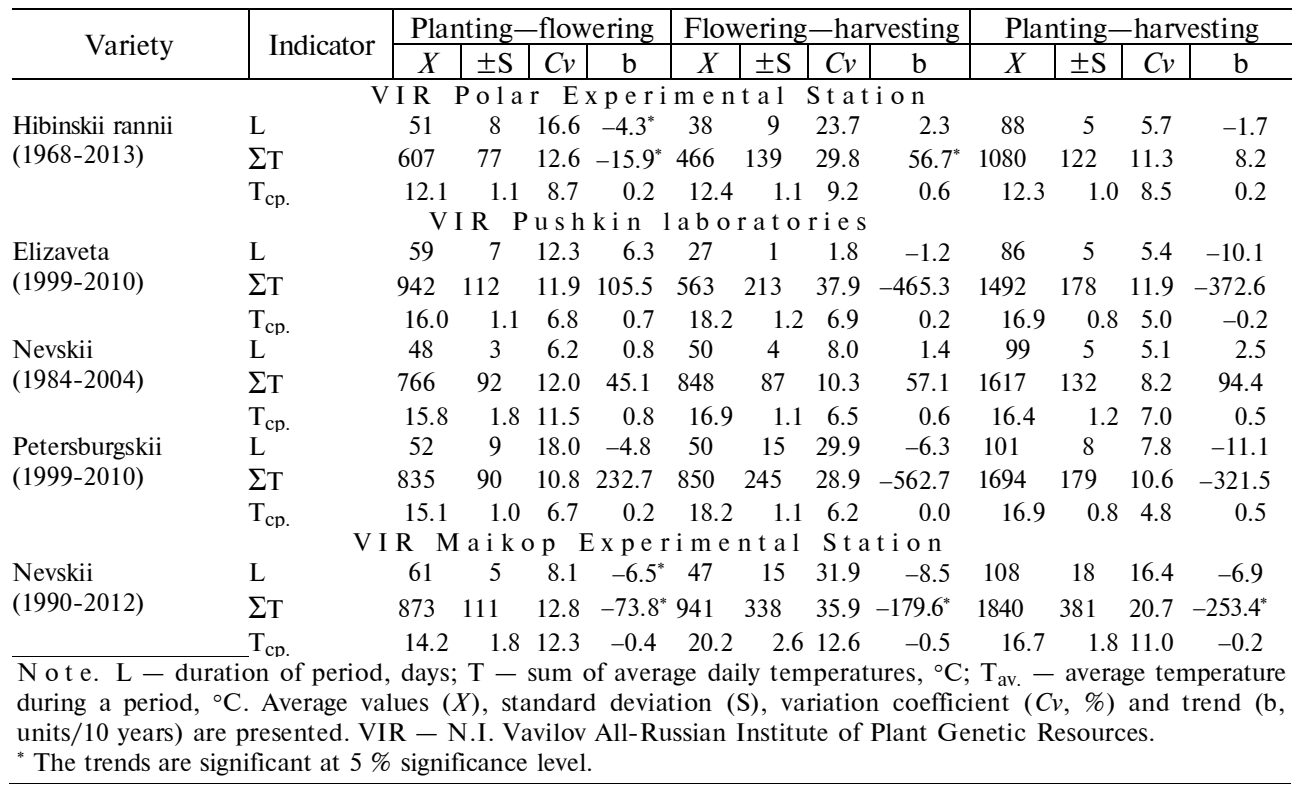

Phe nology. Planting dates of the studied varieties did not change significantly, flowering of the majority of varieties (except for Elizaveta variety) was shifted to earlier periods (at VIR Polar ES by 2.6 days/10 years, $p=0.05$ ), harvesting was also performed earlier. The duration of planting-flowering period at Polar and Maikop experimental stations decreased significantly (Table 1) at the rate of -4.3 and -6.6 days $/ 10$ years. The duration of flowering-harvesting period changed slightly, both toward decrease (at VIR Maikop ES and in Elizaveta and Petersburgskii varieties at VIR Pushkin laboratories) and increase (at VIR Polar ES and in Nevskii variety at VIR Pushkin laboratories). As a result, vegetation 
time decreased in four of five studied varieties. Before 2000 vegetation period in Nevskii variety at VIR Pushkin laboratories decreased as well, after which the planting was shifted to earlier periods; as a result, planting-flowering and planting-harvesting periods became longer.

Temperature conditions of potato growing at VIR Polar ES approached the lower limit of optimum zone (see Table 1), average temperature of planting-emergence period amounted to $9.6 \pm 2.3{ }^{\circ} \mathrm{C}$, and at planting was $8.2 \pm 4.0^{\circ} \mathrm{C}$. At VIR Maikop ES the temperature approached the upper limit of optimum zone and amounted to $20.2 \pm 2.6{ }^{\circ} \mathrm{C}$ during flowering-harvesting, and $22.3 \pm 2.5{ }^{\circ} \mathrm{C}$ at harvesting. Temperature conditions at VIR Pushkin laboratories corresponded to optimum conditions. At VIR Polar ES the sum of average daily temperatures decreased significantly during planting-flowering period with reduction of its duration (by $15.9{ }^{\circ} \mathrm{C}$ per each 10 years), increased during flowering-harvesting (by $56.7^{\circ} \mathrm{C}$ per 10 years), and did not change significantly during the whole vegetation. At VIR Maikop ES the sum of temperatures decreased significantly during planting-emergence, flowering-harvesting and planting-harvesting periods, together with the decrease in duration of these periods (by 73.8; 179.6 and $253.4{ }^{\circ} \mathrm{C} / 10$ years). In Nevskii variety, examined in two geographical points, the duration of planting-flowering and vegetation was significantly longer at VIR Maikop ES, as compared to VIR Pushkin laboratories (61 days vs 48 days and 110 days vs 99 days, respectively); sums of temperatures during these periods also differed significantly (1617 and $\left.1840{ }^{\circ} \mathrm{C}\right)$. Thus, in contrast weather and climatic conditions neither interphase periods of potato varieties, nor the sums of the respective temperatures remain constant.

2. Coefficients of correlation $(r)$ between the duration of interphase periods in reference potato varieties (Solanum tuberosum $\mathrm{L}$.) and the average temperature during the period in observation points with optimum and extreme meteorological conditions

\begin{tabular}{|c|c|c|c|}
\hline Variety & Planting-flowering & Flowering_harvesting & Planting-harvesting \\
\hline \multirow{3}{*}{ Hibinskii rannii (1968-2013) } & VIR Polar Experin & nental Station & \\
\hline & $-0.70^{*}$ & 0.25 & -0.09 \\
\hline & \multicolumn{2}{|c|}{ VIR Pushkin laboratories } & \\
\hline Elizaveta (1999-2010) & -0.09 & -0.21 & -0.06 \\
\hline Nevskii (1984-2004) & -0.17 & -0.14 & -0.19 \\
\hline Petersburgskii (1999-2010) & -0.38 & 0.57 & 0.34 \\
\hline Nevskii (1990-2012) & $\begin{array}{c}\text { VIR Maikop Experi } \\
-0.38\end{array}$ & $\begin{array}{ll}\mathrm{ment} \text { a } \mathrm{s} \text { at } \mathrm{i} \text { on } \\
0.01\end{array}$ & 0.12 \\
\hline
\end{tabular}

Comparison of variation coefficients for the duration of interphase periods and the sums of temperatures during these periods (see Table 1) has demonstrated that the sum of temperatures during the interphase period and the whole vegetation period are generally more variable parameters. The exception was planting-flowering period in several potato varieties at VIR Polar ES and VIR Pushkin laboratories.

Planting-flowering period in potato was regulated by temperature to a greater extent compared to other stages development. The duration of this period in all varieties negatively correlated with the average temperature during the period (Table 2); at that, the strongest correlation was observed at VIR Polar ES $(r=-0.70, \mathrm{p}=0.05)$ at the temperatures approaching the lower limit of optimum zone. Both negative and positive weak and moderate correlations with average temperature were observed for flowering-harvesting and plantingharvesting periods. The strongest positive correlation was observed during flowering-harvesting in mid-ripening variety Petersburgskii $(r=0.57)$. 

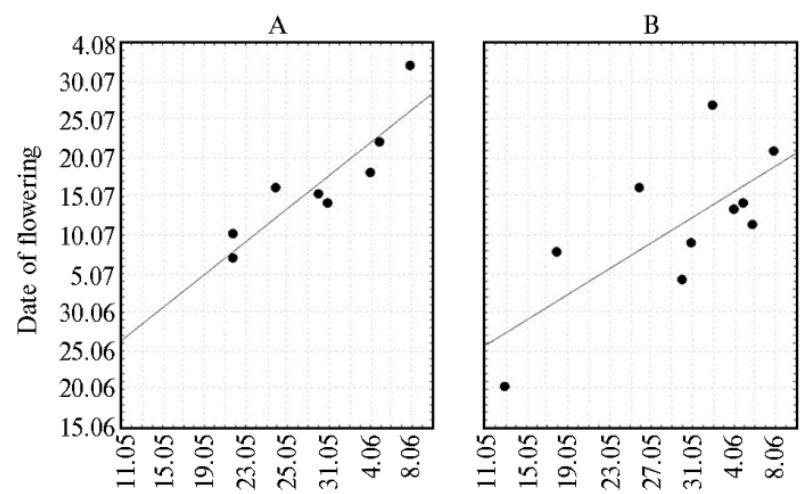

Date of temperature increase above $15^{\circ} \mathrm{C}$

Correlation between flowering initiation periods in potato varieties (Solanum tuberosum L.) Elizaveta (middle-early; A) and Petersburgskii (mid-ripening; B) and temperature increase above $15^{\circ} \mathrm{C}$ (Pushkin laboratories of N.I. Vavilov All-Russian Institute of Plant Genetic Resources, 1990-2010).

increase above $15^{\circ} \mathrm{C}$ at VIR Polar ES $(r=0.46)$ and in Nevskii variety at VIR Pushkin laboratories $(r=0.25)$; the same was observed for the date of flowering initiation date at the same stations in Elizaveta $(r=0.89)$ and Petersburgskii $(r=0.71)$ varieties (Fig.). The duration of planting-flowering (L) at VIR Polar and Maikop experimental stations depended on the sum of active temperatures above $15{ }^{\circ} \mathrm{C}$ $\left(\Sigma \mathrm{T}_{\text {act. }}{ }_{15}\right)$, at Maikop ES also on the planting date $\left(\mathrm{D}_{\mathrm{p}}\right)$, at VIR Pushkin laboratories on the sum of effective temperatures above $15{ }^{\circ} \mathrm{C}\left(\Sigma \mathrm{T}_{\mathrm{ef} .}{ }_{15}\right)$ for Petersburgskii variety, and on the date of stable temperature increase above $15{ }^{\circ} \mathrm{S}\left(\mathrm{D}_{15}\right)$ for Elizaveta variety. In Nevskii variety at VIR Pushkin laboratories the planting-flowering period became longer in case of earlier planting $\left(D_{p}\right)\left(R^{2}\right.$, regression equation determination coefficient):

VIR Polar ES, Hibinskii rannii variety

VIR Pushkin laboratories:

Nevskii variety

Elizaveta variety

Petersburgskii variety

VIR Maikop ES, Nevskii variety

$$
\begin{array}{ll}
\mathrm{L}=64.85-0.04 \Sigma \mathrm{T}_{\text {act. } 15} & \mathrm{R}^{2}=0.63 \\
\mathrm{~L}=79.45-0.60 \mathrm{D}_{\mathrm{p}} & \mathrm{R}^{2}=0.51 \\
\mathrm{~L}=-1.33+0.99 \mathrm{D}_{15} & \mathrm{R}^{2}=0.69 \\
\mathrm{~L}=82.17-0.10 \Sigma \mathrm{T}_{\text {eff. } 15} & \mathrm{R}^{2}=0.78 \\
\mathrm{~L}=90.94-1.04 \mathrm{D}_{\mathrm{p}}-0.01 \Sigma \mathrm{T}_{\text {act. } 15} & \mathrm{R}^{2}=0.49
\end{array}
$$

Further elongation in planting-emergence in potato plants may be expected with temperature increase.

With increase of the sum of active temperatures above $15^{\circ} \mathrm{C}$ floweringharvesting period became longer at VIR Polar ES $(r=0.72)$ and shorter at VIR Maikop ES $(r=-0.54)$. The period from flowering to harvesting in middle-early variety Nevskii at VIR Pushkin laboratories increased in case of earlier planting $(r=0.92)$, in middle-early variety Elizaveta in case of earlier temperature increase above $15{ }^{\circ} \mathrm{C}(r=0.74)$, in mid-ripening variety Petersburgskii with increase of effective temperatures above $15^{\circ} \mathrm{C}(r=0.91)$. In Petersburgskii variety the duration of vegetation also increased with the increase of average active temperature above $15^{\circ} \mathrm{C}$.

Tuber weight per plant and starch content in tubers. According to the literature, tuber weight, the number and yield of tubers per plant are more variable, as compared to the duration of vegetation period [8]. Tuber weight per plant was the most variable parameter in our study (Table 3). In all varieties, except for Nevskii variety at VIR Pushkin laboratories, tuber weight 
per plant increased during the years of study (for VIR Polar ES at $92 \mathrm{~g} / 10$ years, $\mathrm{p}=0.05$ ). Starch content, examined in three varieties (see Table 3 ), increased weakly at VIR Polar ES and decreased in other geographic points.

3. Variability of tuber weight per plant and starch content in tubers of reference potato varieties (Solanum tuberosum $\mathrm{L}_{\text {.) }}$ ) in observation points with optimum and extreme meteorological conditions

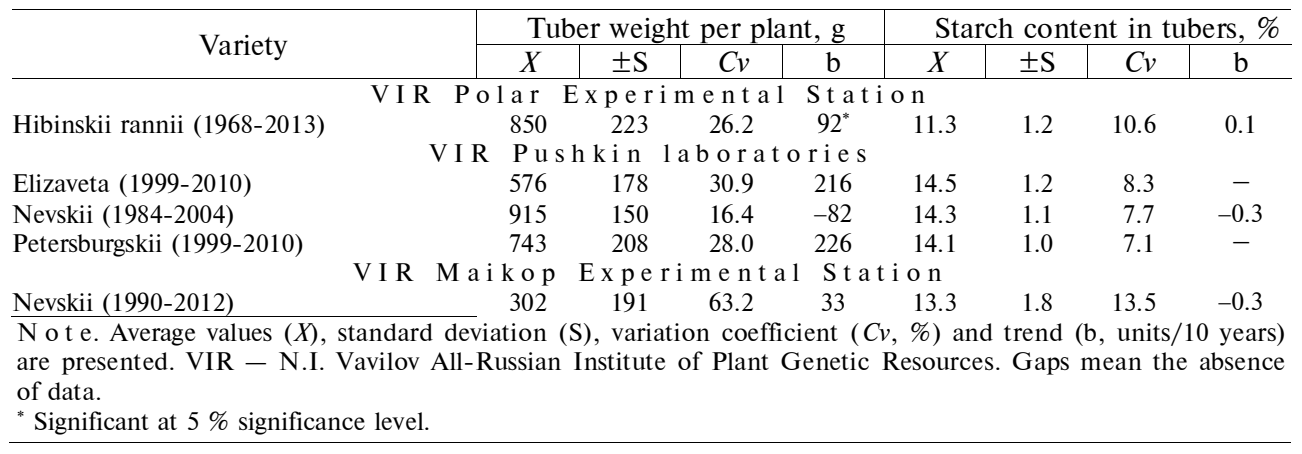

Tuber weight per plant and starch content in tubers correlated with weather conditions to a lesser extent. For example, in Hibinskii rannii variety at VIR Polar ES (1968-2013) tuber weight after harvesting (Y), tuber weight during trial unearthing and average weight of a marketable tuber correlated with the flowering date $\left(\mathrm{D}_{\mathrm{F}}\right)(r=-0.54, r=-0.44$ and $r=-0.52$, respectively $)$ to the greatest extent, i.e. the values of these parameters increased in case of earlier flowering (regression equation for tuber weight per plant at VIR Polar ES is $\mathrm{Y}=2338.134-13.675 \mathrm{D}_{\mathrm{F}}, \mathrm{R}^{2}=0.30$ ). In $1991-2004$ tuber weight per plant increased due to more late harvesting $(r=0.62)$. Further increase of yield can be forecasted in conditions of heat supply increase at VIR Polar ES, resulting from earlier flowering and elongation of flowering-harvesting period

At VIR Pushkin laboratories tuber weight per plant in Nevskii variety decreased with increase in average active temperature above $15^{\circ} \mathrm{C}\left(\mathrm{T}_{15}\right)(r=-0.71)$ (regression equation $\mathrm{Y}=1418.355-146.292 \mathrm{~T}_{15}, \mathrm{R}^{2}=0.51$ ). At VIR Maikop ES in 1990-2012 the weight of tubers per plant of the same Nevskii variety increased in case of earlier budding $\left(D_{B}\right): Y=1228,704-16,289 D_{B}, R^{2}=0,48$.

The models developed suggest increase in potato variety yields under earlier budding and flowering and at longer flowering-harvesting period.

Increase in starch content at VIR Polar ES resulted from increase in the sums of active temperatures above $15{ }^{\circ} \mathrm{C}(r=0.42)$ and more early budding $(r=-0.40)$, and slowed down in the years with greater amount of precipitation in August $(r=-0.30)$ and, as per the regression model, total precipitation during the period with temperatures above $15^{\circ} \mathrm{C}$ [21]. On the contrary, at VIR Maikop ES starch content decreased in more hot years with early budding $(r=0.66)$. At VIR Pushkin laboratories no correlation between the starch content and the studied factors was observed.

The main data obtained, important for forecasting and practical recommendations, may be summarized as follows. Variability of agriculturally valuable potato traits and their correlation with temperature was manifested to the greatest extent in conditions of lack (VIR Polar ES) and excess (VIR Maikop ES) heat. Planting-flowering period of reference varieties decreased at the rate of 2.4 days/10 years at VIR Polar ES, 6.6 days/10 years at VIR Maikop ES, and did not change significantly at VIR Pushkin laboratories. At that, the sums of average daily temperatures during the said period decreased significantly at $-15.9{ }^{\circ} \mathrm{C} / 10$ years and $-73.8^{\circ} \mathrm{C} / 10$ at VIR Polar and Maikop 
experimental stations, respectively, and demonstrated no significant trends at VIR Pushkin laboratories. Decrease in planting-harvesting period was observed in four of five studied potato varieties, also the sum of average daily temperatures during the vegetation period decreased at VIR Maikop ES (at $-253.4^{\circ} \mathrm{C} / 10$ years). In contrast climatic conditions the sums of temperatures during interphase periods of potato varieties were less stable as compared to the duration of the respective periods.

Thus, temperature increase above $15{ }^{\circ} \mathrm{C}$ and more early temperature increase above $15{ }^{\circ} \mathrm{C}$, which accelerate the most weather-dependent phases (emergence and flowering), shall be considered the most important factors of potato plant development in the European Russia territory. The models developed suggest further increase in potato yields in the European Russia territory due to earlier flowering and longer tuber formation period. The variation of starch content in potato tubers has demonstrated no significant trends due to complex regulation of this trait (the increase in temperature increases starch content, while the increase in amount of precipitation decreases it). More early planting of potato may be proposed as a measure of agricultural technology adaptation to climatic changes in the European Russia territory. It is reasonable to continue studying on involvement of more late-ripening varieties for cultivation.

\section{REFERENCES}

1. IPCC Summary for policymakers. In: Climate shange 2014: Impacts, adaptation, and vulnerability. Part A: Global and sectoral aspects. Contribution of Working Group II to the Fifth Assessment Report to the Intergovernmental Panel on Climate Change. C.B. Field, V.R. Barros, D.J. Dokken, K.J. Mach, M.D. Mastrandrea, T.E. Bilir, M. Chatterjee, K.L. Ebi, Y.O. Estrada, R.C. Genova, B. Girma, E.S. Kissel, A.N. Levy, S. MacCracken, P.R. Mastrandrea, L.L. White (eds.). Cambridge University Press, Cambridge, NY, 2014: 1-32.

2. H i j m a ns R.J. The effect of climate change on global potato production. Am. J. Potato Res., 2003, 80: 271-280.

3. Menzel A., von Vopelius J., Estrella N., Schleip C., Dose V. Farmers' annual activities are not tracking speed of climate change. Climate Res., 2005, 32: 201-207.

4. I g l e si a s A., G a r rote L., Q u i rog a S., M o n e o M. Impacts of climate change in agriculture in Europe. PESETA-Agriculture study. Joint Research Centre, Institute for Prospective Technological Studies, Luxembourg, 2009.

5. K a u k ra n t a T., H a k a la K. Impact of spring warming on sowing times of cereal, potato and sugar beet in Finland. Agr. Food Sci., 2008, 17: 165-176.

6. Gordeev A.V., Kleshchenko A.D., C Hernyakov B.A., S i rotenko O.D., Temnikov V.N., Uskov I.B., Romanenkov V.A., Rukhovich D.I. Bioklimaticheskii potentsial Rossii: mery adaptatsii $v$ usloviyakh izmenyayushchegosya klimata /Pod redaktsiei A.V. Gordeeva [Bioclimatic potential of Russia: adaptation to a changing climate. A.V. Gordeev (ed.)]. Moscow, 2008 (in Russ.).

7. Uskov I.B., Uskov A.O. Osnovy adaptatsii zemledeliya $k$ izmeneniyam klimata [Basic adaptations to climat changes in agriculture]. St. Petersburg, 2014 (in Russ.).

8. Grush k a L., Z rust I. V knige: Formirovanie urozhaya osnovnykh sel'skokhozyaistvennykh kul'tur [In: Yield formation in major crops]. Moscow, 1984: 296-328 (in Russ.).

9. Fle isher D., Timlin D.J., Reddy V.R. Temperature influence on potato leaf and branch distribution and on canopy photosynthetic rate. Agron. J., 2006, 98: 1442-1452.

10. Timlin D., Lutfor Rahman S.M., Bake r J., Reddy V.R., Fle isher D., $\mathrm{Q} u$ e b e d e a ux B. Whole plant photosynthesis, development and carbon partitioning of potato as a function of temperature. Agron. J., 2006, 98: 1195-1203.

11. Ab hay a a la K.M.R.D., D e Costa W.A., Fonse ka R.M., Prasannath K., De Costa D.M., Suriyagoda L.D.B. Abeythilakeratne P.D., Nugaliyad d e M.M. Response of potato (Solanum tuberosum L.) to increasing growing season temperature under different soil management and crop protection regimes in the upcountry of Sri Lanka. Tropical Agricultural Research, 2014, 25(4): 555-569.

12. Ko o m a n P.L., H a verkort A.J., Koom a n P.L., Fahem M., T e ge ra P. Effects of climate on different potato genotypes: II. Dry matter allocation and duration of the growth of the growth cycle. Eur. J. Agron., 1996, 5: 207-217.

13. Frusciante L., Barone A., Carputo D., Ranalli P. Breeding and physiological aspects of potato cultivation in the Mediterranean region. Potato Res., 1999, 42: 265-277. 
14. Mel'nichuk G.D., Kostyuk V.I., Kulik ova N.T. Fiziologiya i biokhimiya kartofelya na Kol'skom Severe [Physiology and biochemistry of potatoes in the Kola North]. Apatity, 1997 (in Russ.).

15. Korovin A.I. Rasteniya $i$ ekstremal'nye temperatury [Plants and extreme temperatures]. Leningrad, 1984 (in Russ.).

16. Razukas A., Jankauskiene Z., Jundulas J., Asakaviciute R. Research of technical crops (poato and flax) genetic resources in Lithuania. Agronomy Research, 2009, 7(1): 59-72.

17. Haverkort A.J., Franke A.C., Steyn J.M., Pronk A.A., Caldiz D.O., Koom a n P.L. A Robust Potato Model: LINTUL-POTATO-DSS. Potato Res., 2015, 58: 313-327.

18. Rykaczewska K. The impact of high temperature during growing season on potato cultivars with different response to environmental stresses. Am. J. Plant Sci., 2013, 4: 2386-2393.

19. Belolyubtsev A.I., Sennikov V.A. Bioklimaticheskii potentsial ekosostem [Bioclimatic potential of biosystems]. Moscow, 2012 (in Russ.).

20. S u k hove e va O.E. Geografiya i prirodnye resursy, 2014, 2: 71-77 (in Russ.).

21. Mel'nik Yu.S., Gulinova N.V., Bedarev S.A. Rukovodstvo po agrometeorologicheskim prognozam. Tom 2. Tekhnicheskie, ovoshchnye, plodovye, subtropicheskie kul'tury, travy, pastbishchnaya rastitel'nost', otgonnoe zhivotnovodstvo [Guide to Agrometeorological forecasts. V. 2. Technical, vegetable, fruit, subtropical crops, grass, pasture vegetation, transhumance]. Leningrad, 1984 (in Russ.).

22. $\mathrm{M}$ is h c he n k o Z.A. Agroklimatologiya [Agroclimatology]. Kiev, 2009 (in Russ.)..

23. Kiru S.D., Novikova L.Yu., Dyubin V.N. Materialy mezhdunarodnoi nauchnoprakticheskoi konferentsii "Nauchnoe obespechenie razvitiya APK v usloviyakh reformirovaniya», chast' 1 [Proc. Int. Conf. «Scientific support for the development of agro-industrial complex in the conditions of reforming»]. St. Petersburg, 2013, part 1: 54-57 (in Russ.).

24. Novikova L.Yu., Loskutov I.G., Zuev E.V., Porokhovinova E.A., Artem'eva A.M., Kiru S.D., Rogozina E.V. Agro XXI, 2015, 1-3: 6-8 (in Russ.).

25. Novikova L.Yu., Travina S.N., Zhigadlo T.E., Naumova L.G., Zuev E.V. Trudy po prikladnoi botanike, genetike i selektsii, 2015, 176(4): 391-401 (in Russ.).

26. Novikova L.Yu., Kiru S.D., Rogozina E.V. Materialy mezhdunarodnoi konferentsii «Problemy sistematiki i selektsii kartofelya» [Proc. Int. Conf. «Potato systematics and breeding»]. St. Petersburg, 2016: 75-77 (in Russ.). 